\title{
Fatigue Behavior of Metastable and Stable Austenitic Steels*
}

\author{
By Susumu HORIBE, ,* Yuichi SEKI, ${ }^{* * *}$ Toshio FUJITA*** \\ and Toru ARAKI****
}

\begin{abstract}
Synopsis
An attempt has been made to survey the fatigue behavior of three different austenitic steels. The materials tested are $\mathrm{Fe}-30 \mathrm{Ni}$ alloy as metastable austenite, $\mathrm{Fe}-38 \mathrm{Ni}$ alloy as stable austenite and $\mathrm{Fe}-25 \mathrm{Ni}-16 \mathrm{Cr}$ alloy of low stacking fault energy. It was found that at low stress amplitudes the fatigue life of the metastable steel was longer than that of the stable ones, while at high stress amplitudes the metastable steel was inferior to the stable ones. This is probably attributed to the differences of the rate and period of martensite formation. The fatigue life of the $\mathrm{Fe}-$ $25 \mathrm{Ni}-16 \mathrm{Cr}$ alloy was less than that of the $\mathrm{Fe}-38 \mathrm{Ni}$ alloy only at high stress amplitudes. The $\mathrm{Fe}-30 \mathrm{Ni}$ alloy showed a remarkable hardening with martensite formation, but its cyclic strain behavior except for the hardening due to the martensite formation was extremely similar to that of the $\mathrm{Fe}-38 \mathrm{Ni}$ alloy, that is, at high stress amplitudes a remarkable hardening occurred and at low stress amplitudes softening occurred slightly. Fatigue crack propagation property of the $\mathrm{Fe}-30 \mathrm{Ni}$ alloy was also better than that of the $\mathrm{Fe}-38 \mathrm{Ni}$ alloy at a low $\Delta K$ level, but at a high $\Delta K$ level the former was inferior to the latter.
\end{abstract}

\section{Introduction}

The effects of retained austenite on fatigue behaviors of steels have been discussed by several investigators. ${ }^{1-8)}$ In some reports the retained austenite is cited as beneficial for fatigue strength, ${ }^{1,6-8)}$ but in others it is reported to be rather harmful. ${ }^{2,3)}$ The effects of retained austenite on the fatigue behavior are presumably dependent on the alloy compositions, volume fraction and stability of retained austenite, and experimental methods. Because of these complicated situations, this problem has not been sufficiently studied and contains many difficult matters awaiting solution.

There has been relatively little research conducted concerning the fatigue behavior of austenitic steels, but in recent years such studies ${ }^{9-12)}$ has steadily increased with an increasing demand for austenitic stainless steels.

In the present paper $\mathrm{Fe}-30 \mathrm{Ni}$ alloy as metastable austenite, $\mathrm{Fe}-38 \mathrm{Ni}$ alloy as stable austenite and $\mathrm{Fe}-$ $25 \mathrm{Ni}-16 \mathrm{Cr}$ alloy of low stacking fault energy were tested so that (1) fatigue properties (fatigue damage, crack initiation, and crack propagation), (2) effect of martensite transformation on the fatigue behavior and (3) effect of stacking fault energy (S.F.E.) on the fatigue behavior were established from the microstructural point of view.

\section{Experimental Procedure}

\section{Materials and Heat Treatment}

Materials were vacuum melted, annealed at $1150^{\circ} \mathrm{C}$ and rolled to $6 \mathrm{~mm}$ plates and $10 \mathrm{~mm}$ diameter rods. Tensile specimens and fatigue specimens were machined to the same size as that described in the previous papers. ${ }^{13,14)}$ The chemical composition of materials are given in Table 1 .

All specimens were heated at $900^{\circ} \mathrm{C}$ for $1 \mathrm{hr}$ and cooled in a vacuum furnace. The austenite grain size was $35.2 \mu \mathrm{m}$ in $\mathrm{Fe}-30 \mathrm{Ni}$ alloy, $47.2 \mu \mathrm{m}$ in $\mathrm{Fe}-38 \mathrm{Ni}$ alloy and $33.6 \mu \mathrm{m}$ in $\mathrm{Fe}-25 \mathrm{Ni}-16 \mathrm{Cr}$ alloy. For the purpose of obtaining the same grain-sized specimens, other annealing conditions were adopted $-1 \mathrm{hr}$ at $935^{\circ} \mathrm{C}$ for $\mathrm{Fe}-30 \mathrm{Ni}$ alloy and $1 \mathrm{hr}$ at $950^{\circ} \mathrm{C}$ for $\mathrm{Fe}-25 \mathrm{Ni}-16 \mathrm{Cr}$ alloy. The grain size of these heat treated specimens was approximately equal to that of the $\mathrm{Fe}-38 \mathrm{Ni}$ alloy.

\section{Tensile Test and Fatigue Test}

Tensile tests were conducted at $-196^{\circ},-70^{\circ}, 20^{\circ}$ and $98^{\circ} \mathrm{C}$ in order to obtain the data of conventional mechanical properties and stability of austenitic phases in each specimen.

Fatigue tests were conducted at $20^{\circ} \mathrm{C}$. Fatigue damage tests were carried out in fully reversed bending using a Schenck type fatigue machine, the frequency of which was $450 \mathrm{cpm}$. The variation of strain amplitudes under constant applied stresses was measured dynamically. ${ }^{13)}$ To provide a quantitative estimate of the martensite formed in $\mathrm{Fe}-30 \mathrm{Ni}$ alloy during fatigue cycling, X-ray diffraction method was used. The amount of austenite $V_{r}$ was calculated by Eq. $(1) ;^{15)}$

Table 1. Chemical composition of materials. (wt \%)

\begin{tabular}{|c|c|c|c|c|c|c|c|c|c|}
\hline & $\mathrm{C}$ & $\mathrm{Si}$ & Mn & $\mathrm{P}$ & $\mathrm{S}$ & $\mathrm{Ni}$ & $\mathrm{Cr}$ & $\mathrm{Al}$ & $\mathrm{N}$ \\
\hline $\mathrm{Fe}-30 \mathrm{Ni}$ & 0.005 & 0.003 & 0.002 & 0.004 & 0.003 & 30.14 & - & 0.018 & 0.0012 \\
\hline $\mathrm{Fe}-38 \mathrm{Ni}$ & 0.004 & 0.006 & 0.001 & 0.004 & 0.003 & 37.89 & - & 0.015 & 0.0014 \\
\hline $\mathrm{Fe}-25 \mathrm{Ni}-16 \mathrm{Cr}$ & 0.002 & 0.007 & 0.002 & 0.004 & 0.006 & 24.39 & 15.63 & $<0.001$ & 0.0048 \\
\hline
\end{tabular}

* Originally published in Tetsu-to-Hagané, 64 (1978), 278, in Japanese. English version received August 8, 1979.

** Tsukuba Laboratories, National Research Institute for Metals, Sengen, Sakuramura, Niihari-gun, Ibaraki 305.

*** Department of Metallurgy and Materials Science, The University of Tokyo, Hongo, Bunkyo-ku, Tokyo 113.

**** National Research Institute for Metals, Nakameguro, Meguro-ku, Tokyo 153. 


$$
V_{\gamma}=1.4 I_{\gamma} /\left(I_{\alpha}+1.4 I_{\gamma}\right)
$$

where $I_{\gamma}$ was the average of integrated intensity from $(220)_{\gamma}$ and $(311)_{\gamma}$, and $I_{\alpha}$ was the integrated intensity from $(211)_{\alpha}$. The microstructure for each specimen was studied by optical microscopy to establish the morphological changes of the specimen surface and site of crack initiation. The specimens that had failed due to fatigue were examined by transmission electron microscopy.

Fatigue crack propagation tests were conducted on notched specimens at a frequency of $1000 \mathrm{cpm}$ by applying in-plane bending stress (stress ratio $R=$ 0.06). The notch length $d_{o}$ was $2 \mathrm{~mm}$. Fatigue fractured surface was observed by scanning electron microscopy.

\section{Experimental Results}

\section{Tensile Test}

Figure 1 presents the tensile properties of three alloys with five different microstructures at a temperature range of $-196^{\circ}$ to $98^{\circ} \mathrm{C}$. In $\mathrm{Fe}-30 \mathrm{Ni}$ alloy $M_{s}$ temperature is about $-20^{\circ} \mathrm{C}$, and $M_{d}$ temperature seems to be approximately room temperature $(R T)$, so the elongation is maximum near $R T$ and extremely low at $-70^{\circ} \mathrm{C}$ and $-196^{\circ} \mathrm{C}$. The tensile strength increases with decreasing test temperature, but in the specimens tested below $-70^{\circ} \mathrm{C}$, they fracture almost without elongation because of the martensite formation prior to the deformation. Although it is reported that $M_{d}$ temperature and $M_{s}$ temperature of $\mathrm{Fe}-38 \mathrm{Ni}$ alloy are approximately $-150^{\circ} \mathrm{C}$ and below $-196^{\circ} \mathrm{C},{ }^{16)}$ respectively, deformation-induced transformation martensite was not detected by optical or electron microscopy in the present experiment. In $\mathrm{Fe}-25 \mathrm{Ni}-16 \mathrm{Cr}$ alloy whose stability in Schaeffler's diagram is equal to that of $\mathrm{Fe}-38 \mathrm{Ni}$ alloy, the elongation is minimum at $R T$. Breedis and Robertson ${ }^{17,18)}$ reported that the $\mathrm{Fe}-25 \mathrm{Ni}-16 \mathrm{Cr}$ single crystal did not transform to martensite either by cooling to $-269^{\circ} \mathrm{C}$ or by deforming at $-196^{\circ} \mathrm{C}$, and the martensite formation was not detected in the present experiment. Thus, it is considered that the increase of the elongation in the low temperature range originates from factors other than the transformation induced plas- ticity, ${ }^{19,20)}$ although this question is unresolved in this report.

\section{Fatigue Test}

\section{S-N Curves}

Figure 2 exhibits the $\mathrm{S}-\mathrm{N}$ curves in three steels, i.e., Fe-30Ni alloy (900), Fe-38Ni alloy (900) and Fe-25Ni-16Cr alloy (950) which are of approximately the same strength level. The metastable austenite $\mathrm{Fe}-30 \mathrm{Ni}$ alloy has a favourable fatigue resistance as compared with other alloys in a low stress amplitude range of $\sigma_{a}<33 \mathrm{~kg} / \mathrm{mm}^{2}$, however the fatigue property of this alloy deteriorates remarkably with the increase of the applied stress and consequently becomes inferior to other alloys in a high stress amplitude range of $\sigma_{a}>38 \mathrm{~kg} / \mathrm{mm}^{2}$. Fatigue resistance of $\mathrm{Fe}-25 \mathrm{Ni}-16 \mathrm{Cr}$ alloy is inferior to that of $\mathrm{Fe}-38 \mathrm{Ni}$ alloy at high stress amplitudes because the proof stress of this alloy is low, but the difference in the fatigue life in both alloys becomes less pronounced at low stress amplitudes.

\section{Cyclic Plastic Behavior}

The variations of plastic strain amplitudes in $\mathrm{Fe}-$ $30 \mathrm{Ni}$ alloy $(900,935)$ are presented in Figs. 3 and 4. Comparison of the figures shows that the cyclic plastic behaviors do not depend so much on the austenite grain size. At high stress amplitudes, strain amplitudes of both specimens decrease remarkably

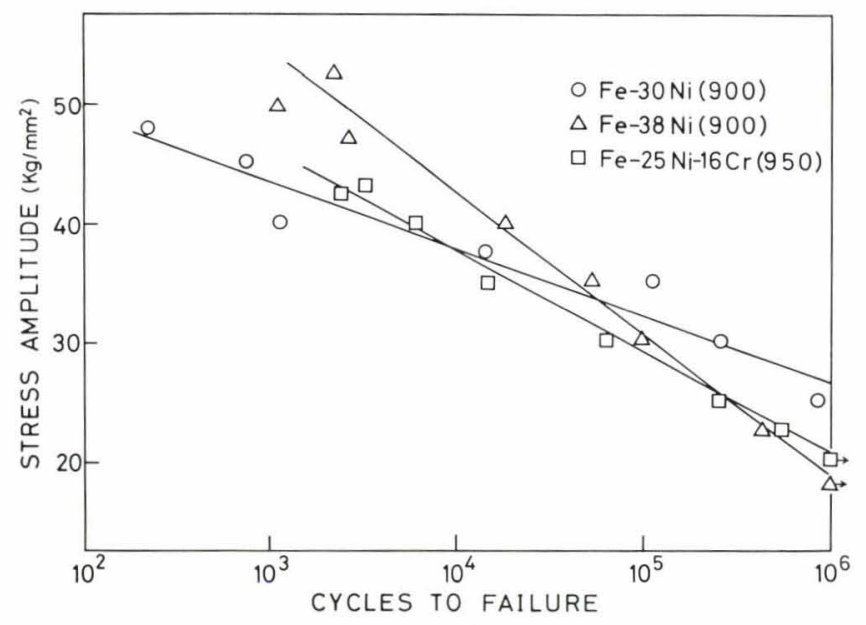

Fig. 2. S-N curves of austenitic steels.
Fig. 1. Relationship between mechanical properties and test temperature.

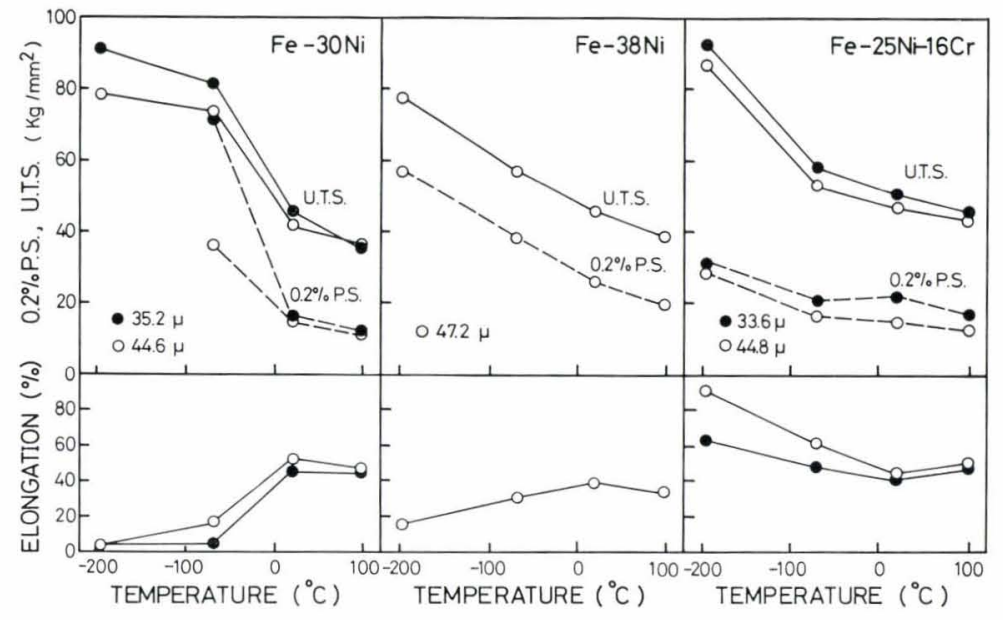


(hardening) and at a low stress amplitude ( $\sigma_{a}=$ $14 \mathrm{~kg} / \mathrm{mm}^{2}$ ), strain amplitude increases slightly (softening) until $3 \times 10^{3}$ cycles and decreases afterwards. It is considered that the hardening is attributed mainly to martensite formation, but presumably other factors are also related to the hardening. The martensite formation process in this alloy was examined from

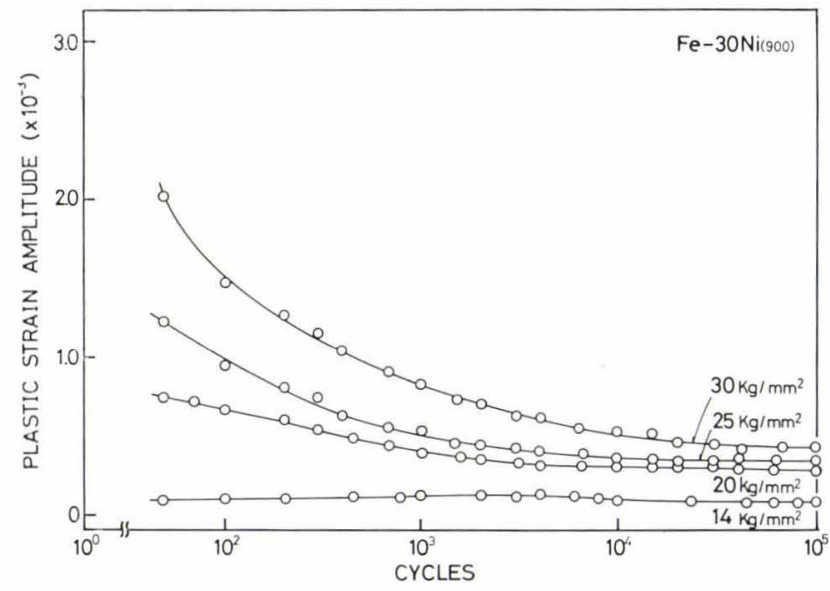

Fig. 3. Variation of plastic strain amplitude during testing: $\mathrm{Fe}-30 \mathrm{Ni}(900)$.

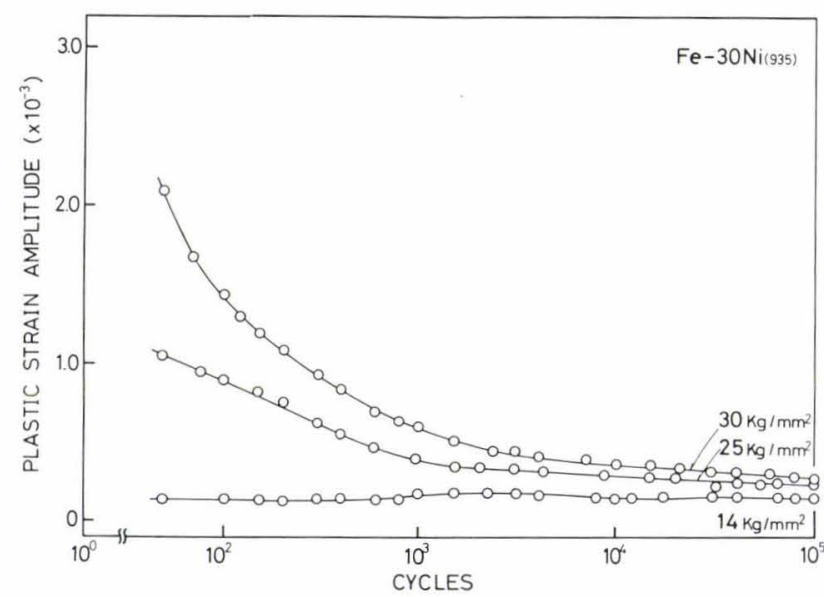

Fig. 4. Variation of plastic strain amplitude during testing: $\mathrm{Fe}-30 \mathrm{Ni}(935)$. this point of view (Fig. 5). Surface martensite is easily formed in this alloy, and in fact $6 \sim 7 \%$ surface martensite was detected on the specimen surface prior to cyclic deformation. When this alloy was tested at high stress amplitudes $\left(\sigma_{a}=25\right.$ to $\left.30 \mathrm{~kg} / \mathrm{mm}^{2}\right)$, martensite was rapidly produced for up to $10^{3}$ cycles, and then martensite formation rate gradually decreased. When it was tested at a low stress amplitude $\left(\sigma_{a}=20 \mathrm{~kg} / \mathrm{mm}^{2}\right)$, the martensite was formed relatively slowly in early cycles, but even in the last stage martensite transformation tended to occur gradually.

The transmission electron micrographs of specimens after being fatigued at $\sigma_{a}=48 \mathrm{~kg} / \mathrm{mm}^{2}$ and $25 \mathrm{~kg} / \mathrm{mm}^{2}$ are shown in Photos. 1 (a) and (b), respectively. The morphology of the induced martensite does not seem to depend on these different stress levels and consists of lath type martensite with twin type martensite rarely seen.

The variation of the strain amplitudes in $\mathrm{Fe}-38 \mathrm{Ni}$ alloy (900) is presented in Fig. 6. In this alloy no such remarkable decrease of strain amplitude as that observed in $\mathrm{Fe}-30 \mathrm{Ni}$ alloy was detected since martensite transformation did not occur during cycling at RT. However, even this alloy revealed a tendency of hardening at an extremely high stress amplitude

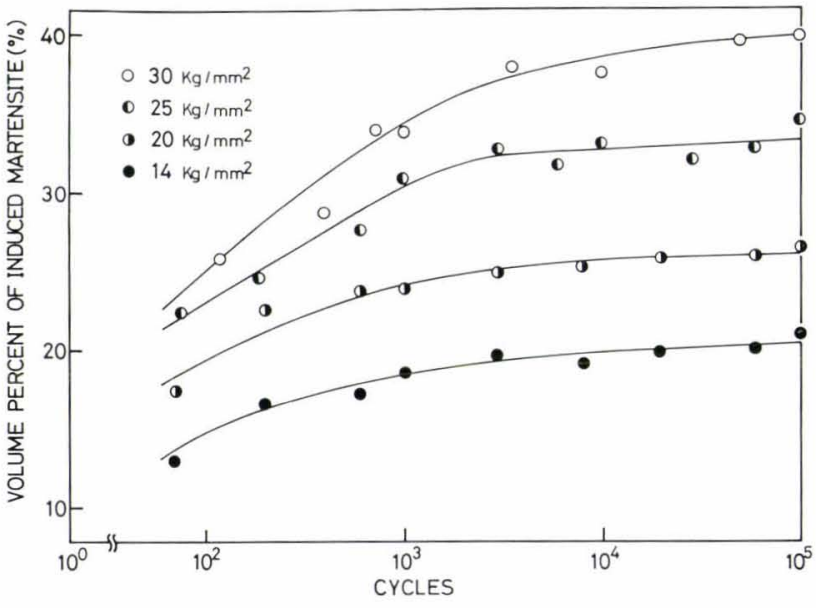

Fig. 5. Change of the volume fraction of martensite during testing: $\mathrm{Fe}-30 \mathrm{Ni}(900)$.
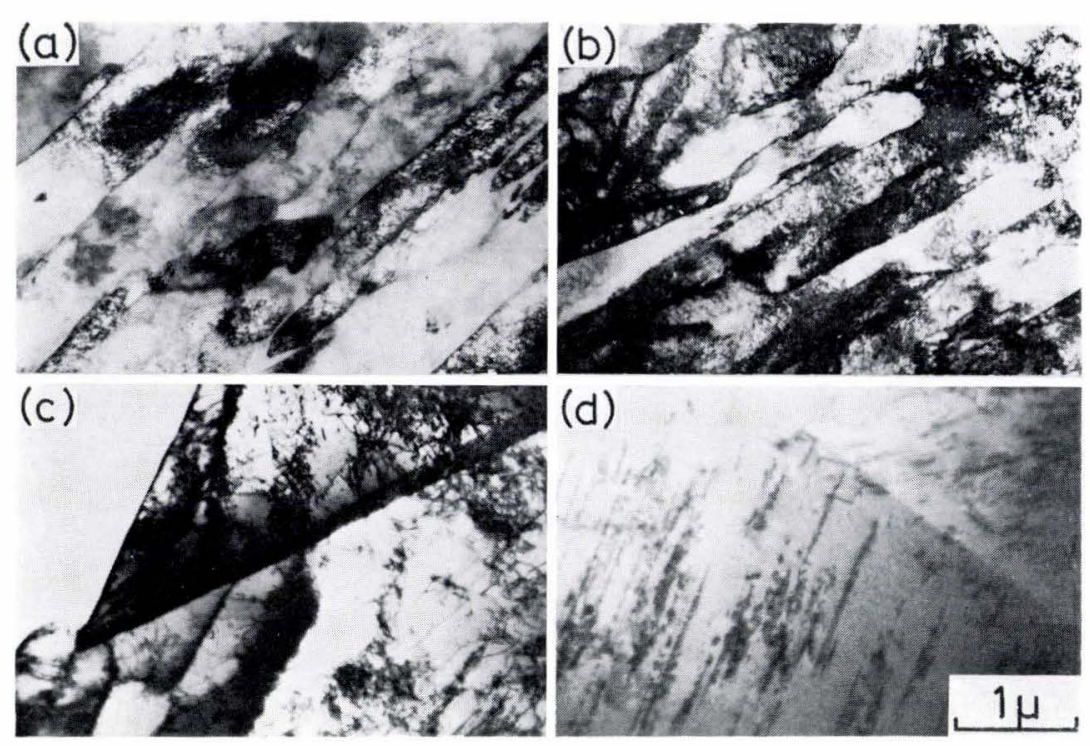

(a) $\mathrm{Fe}-30 \mathrm{Ni}(900): \sigma_{a}=48 \mathrm{~kg} / \mathrm{mm}^{2}$

(b) $\mathrm{Fe}-30 \mathrm{Ni}(900): \sigma_{a}=25 \mathrm{~kg} / \mathrm{mm}^{2}$

(c) $\mathrm{Fe}-38 \mathrm{Ni}(900): \sigma_{a}=25 \mathrm{~kg} / \mathrm{mm}^{2}$

(d) $\mathrm{Fe}-25 \mathrm{Ni}-16 \mathrm{Cr}(950): \sigma_{a}=25 \mathrm{~kg} / \mathrm{mm}^{2}$

Photo. 1.

Transmission electron micrographs of specimens fatigued to failure. 
$\left(\sigma_{a}=37.5 \mathrm{~kg} / \mathrm{mm}^{2}\right)$. At a medium stress amplitude $\left(\sigma_{a}=30 \mathrm{~kg} / \mathrm{mm}^{2}\right)$ the alloy initially hardened a little, and kept strains constant or softened slightly in the range of $3 \times 10^{2}$ to $3 \times 10^{3}$ cycles. Below $0.2 \%$ proof stress the softening continued until $3 \times 10^{3}$ cycles followed by hardening. The dislocation structures of this steel after fatigue are shown in Photo. 1 (c).

The variation of strain amplitudes in $\mathrm{Fe}-25 \mathrm{Ni}-$ $16 \mathrm{Cr}$ alloy (Fig. 7) reveals that this alloy hardens throughout its entire life. This tendency was remarkable at high stress amplitudes. The plastic behavior of this alloy did not depend on the grain size. Photograph 1 (d) shows the structure of the specimen that failed at the same cycles as $\mathrm{Fe}-38 \mathrm{Ni}$ alloy (Photo. 1 (c)), and noticeable morphological differences in both specimens have been observed.

\section{Change of Surface Morphology}

Photographs 2 to 4 exhibit the surface of three alloys fatigued to failure. In $\mathrm{Fe}-30 \mathrm{Ni}$ alloy fatigue cracks initiated preferentially in pre- $\gamma$ boundaries at high stress amplitudes, whereas at low stress amplitudes they nucleated, in addition to these sites, along the interface of the austenite and the martensite that had existed prior to cycling or that was formed in

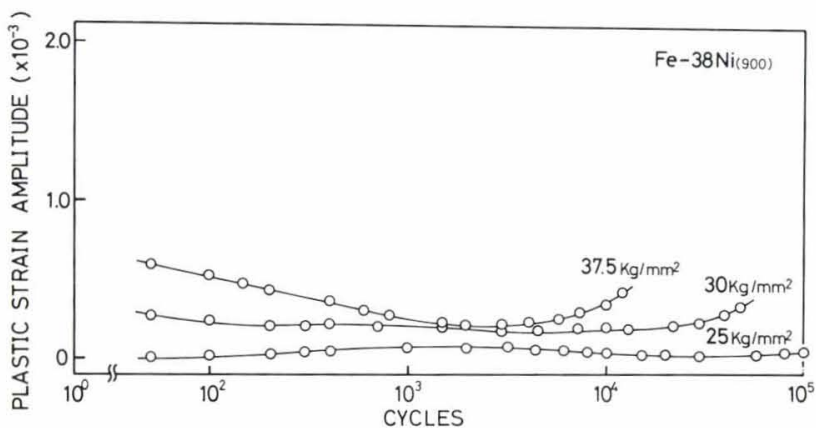

Fig. 6. Variation of plastic strain amplitude during testing: $\mathrm{Fe}-38 \mathrm{Ni}(900)$

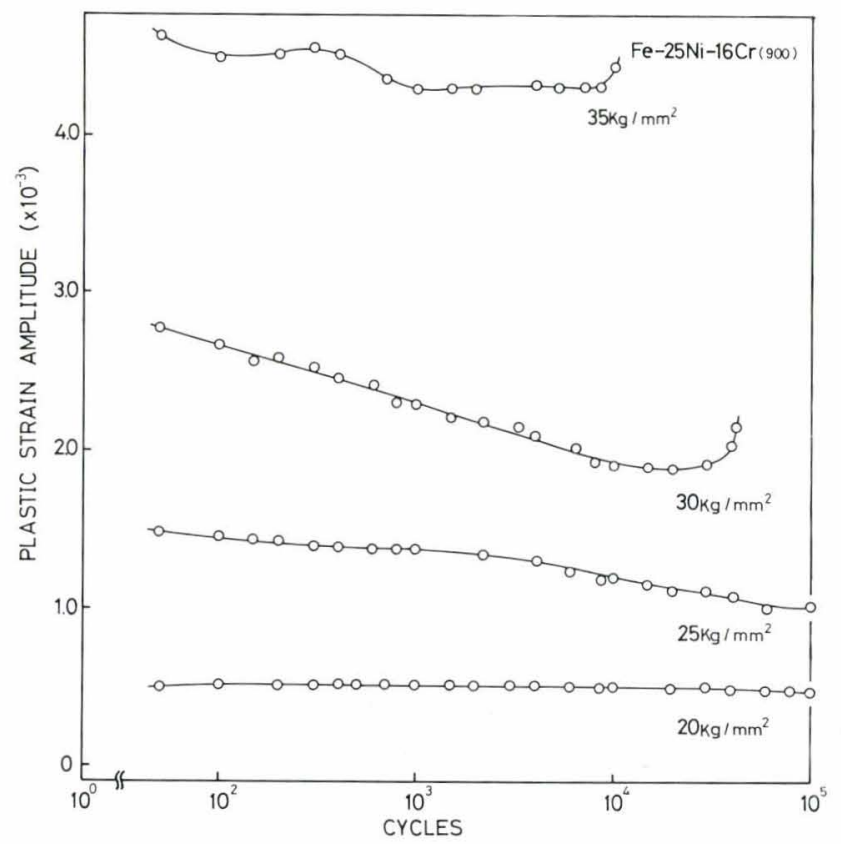

Fig. 7. Variation of plastic strain amplitude during testing: $\mathrm{Fe}-25 \mathrm{Ni}-16 \mathrm{Cr}(900)$ early cycles. In $\mathrm{Fe}-38 \mathrm{Ni}$ and $\mathrm{Fe}-25 \mathrm{Ni}-16 \mathrm{Cr}$ alloys fatigue cracks initiated along $\gamma$ boundaries at higher stress amplitudes. However, with a decrease of applied stress, the number of these crack initiations
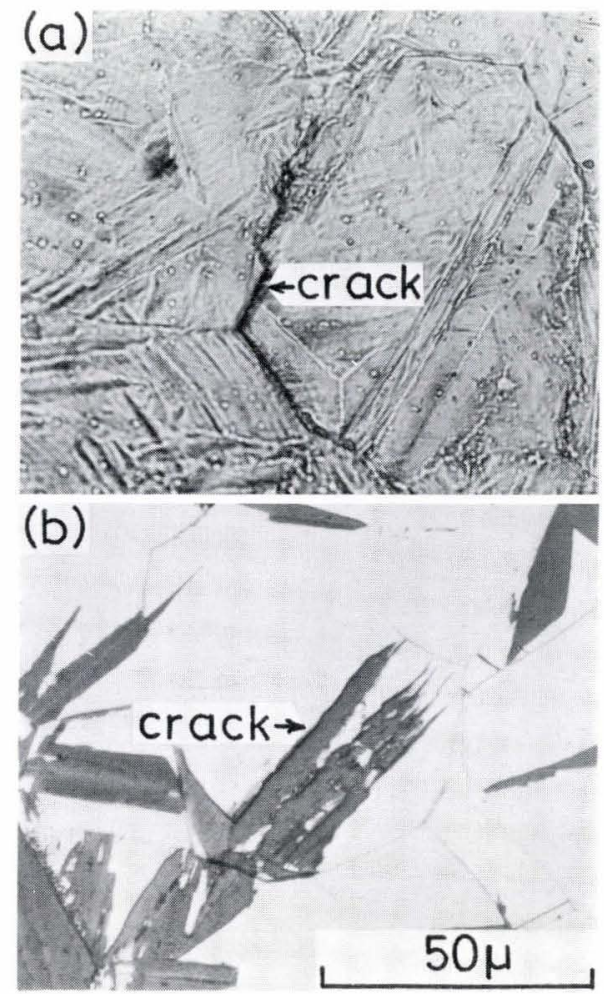

(a) $\sigma_{a}=48 \mathrm{~kg} / \mathrm{mm}^{2}$

(b) $\sigma_{a}=25 \mathrm{~kg} / \mathrm{mm}^{2}$

Photo. 2. Slip bands and fatigue cracks on the surface of Fe 30Ni(900).
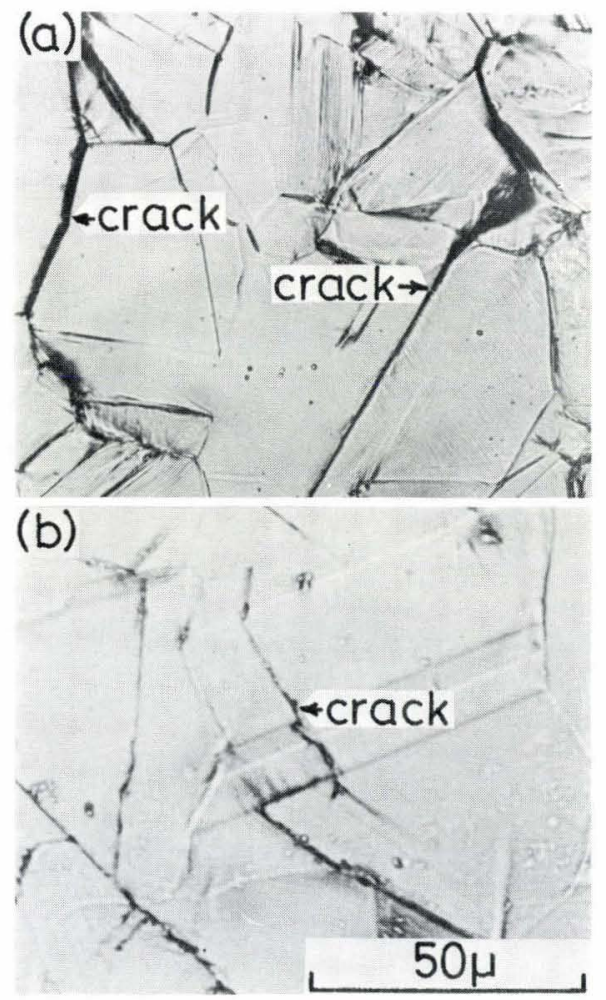

(a) $\sigma_{u}=48 \mathrm{~kg} / \mathrm{mm}^{2}$

(b) $\rho_{a}=30 \mathrm{~kg} / \mathrm{mm}^{2}$

Photo. 3. Slip bands and fatigue cracks on the surface of Fe$38 \mathrm{Ni}(900)$ 
decreased remarkably and the number of cracks along the slip bands increased.

\section{Fatigue Grack Propagation}

Figure 8 presents fatigue crack propagation rate as a function of stress intensity factor range $\Delta K$ for each structure. This stress intensity factor was calculated by using Gross's equation. ${ }^{21)}$ The coefficient $C$ and the exponent $m$ in the fatigue crack growth equation, $d a / d \mathcal{N}=C(\Delta K)^{m}$, are given in these figures. This result indicates that crack propagation properties do not depend on the grain size.

The comparison of the crack propagation prop-
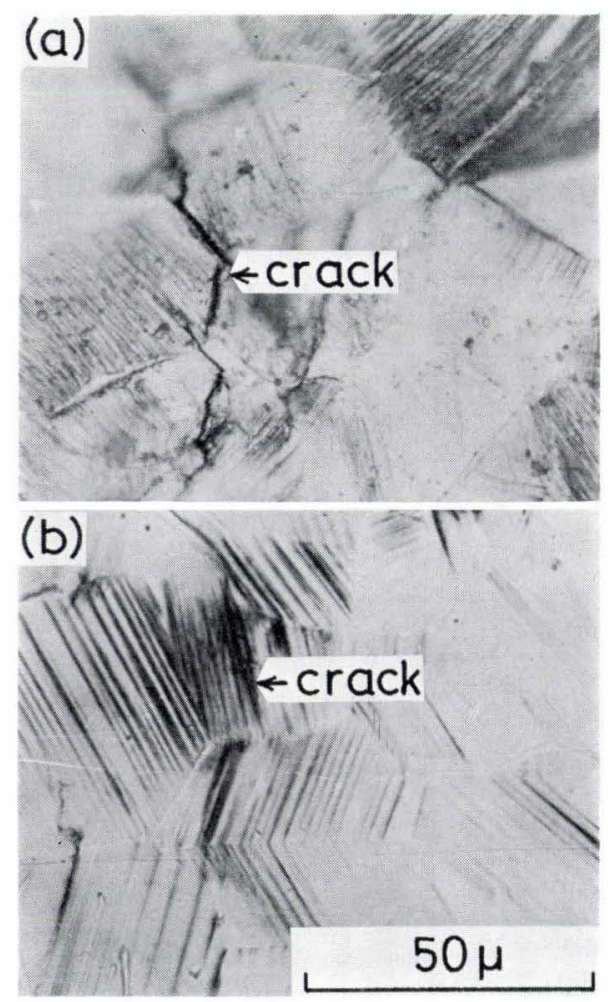

$\begin{array}{ll}\text { (a) } \sigma_{a}=45 \mathrm{~kg} / \mathrm{mm}^{2} & \text { (b) } \sigma_{a}=25 \mathrm{~kg} / \mathrm{mm}^{2}\end{array}$

Photo. 4. Slip bands and fatigue cracks on the surface of Fe$25 \mathrm{Ni}-16 \mathrm{Cr}(950)$. erties for each alloy shown in Fig. 9 reveals that the crack propagation rate of $\mathrm{Fe}-30 \mathrm{Ni}$ alloy is lower than of $\mathrm{Fe}-38 \mathrm{Ni}$ alloy at low $\Delta K$ level, but it is opposite at high $\Delta K$ level, and that the propagation property of $\mathrm{Fe}-25 \mathrm{Ni}-16 \mathrm{Cr}$ alloy is superior to that of $\mathrm{Fe}-30 \mathrm{Ni}$ alloy or $\mathrm{Fe}-38 \mathrm{Ni}$ alloy over the entire $\Delta K$ range. Micrographs of the fatigue fractured surfaces are shown in Photos. 5 to 7.

\section{Discussion}

1. Fatigue Properties of Metastable Austenite (Fe-30Ni)

Figure 10 shows the interrelationship between the variation of cyclic strain amplitude in Fig. 3 and that of martensite formed on the specimen in Fig. 5. The abscissa is the rate of the martensite formation, $d V_{\alpha}$ l $d(\log \mathcal{N})$, and the ordinate is the rate of hardening, $d \varepsilon_{p} / d(\log \mathcal{N})$. Both values were plotted at each number of cycles. On each curve lower-right plots are of low cycles and upper-left plots are of high cycles. If the hardening is due to the martensite

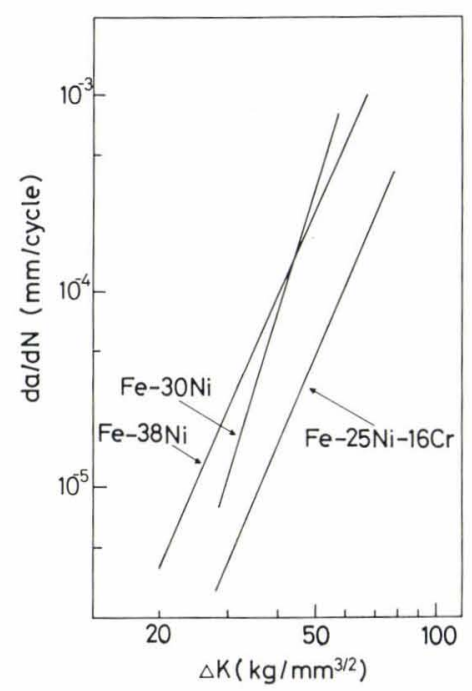

Fig. 9. Comparison of fatigue crack propagation rate as a function of stress intensity factor range.

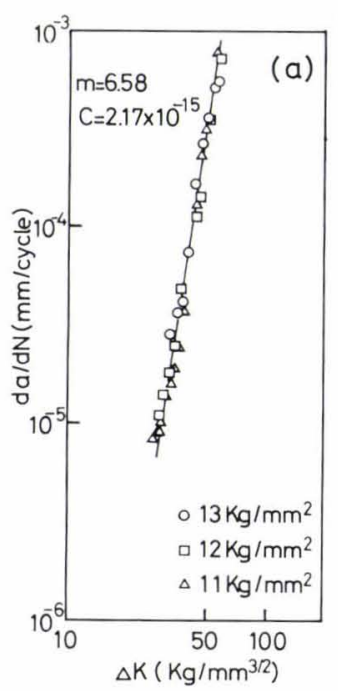

(a) $\mathrm{Fe}-30 \mathrm{Ni}(900)$

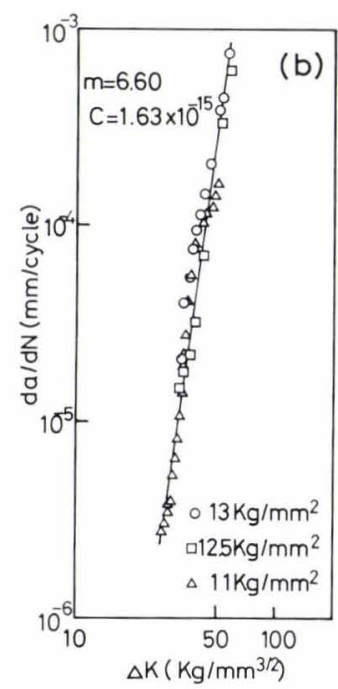

(b) $\mathrm{Fe}-30 \mathrm{Ni}(935)$

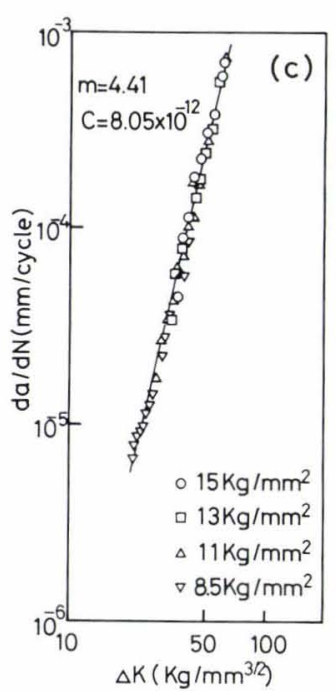

(c) $\mathrm{Fe}-38 \mathrm{Ni}(900)$

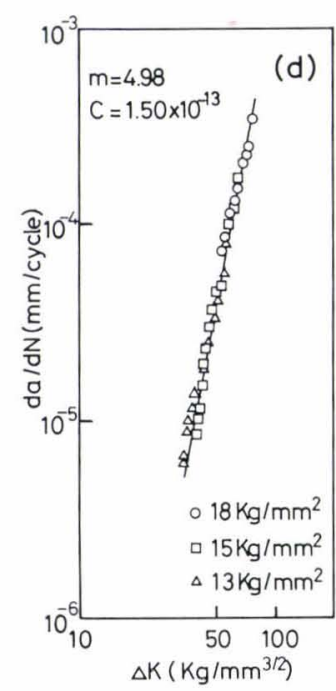

(d) $\mathrm{Fe}-25 \mathrm{Ni}-16 \mathrm{Cr}(900)$

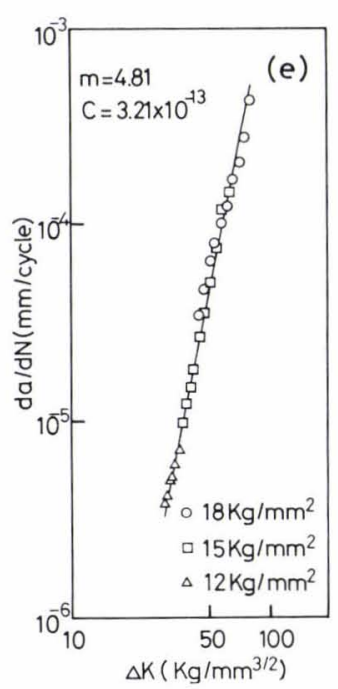

(e) $\mathrm{Fe}-25 \mathrm{Ni}-16 \mathrm{Cr}(950)$

Fig. 8. Fatigue crack propagation rate as a function of stress intensity factor range. 

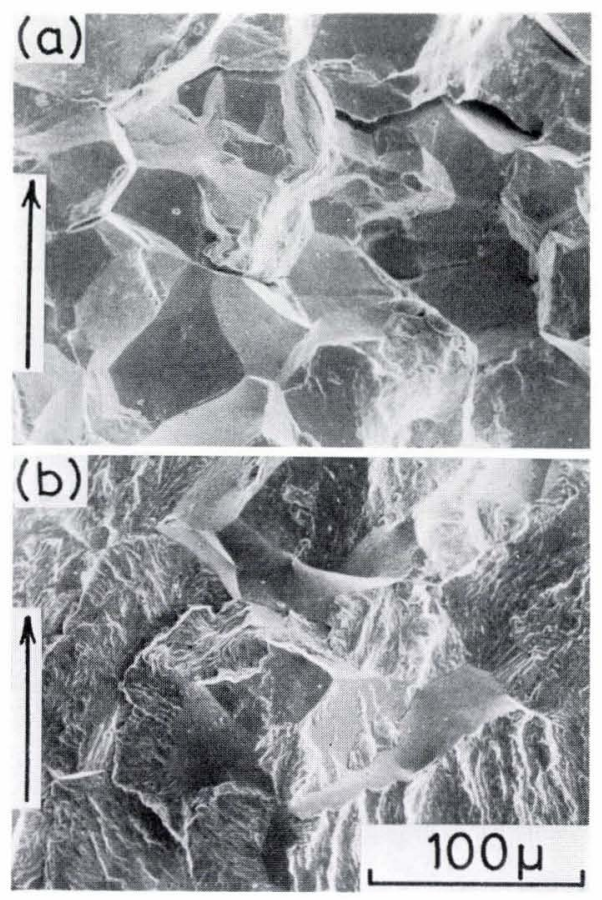

(a) $\Delta K=60 \mathrm{~kg} / \mathrm{mm}^{3 / 2}$

(b) $\Delta K=28 \mathrm{~kg} / \mathrm{mm}^{3 / 2}$

Photo. 5. Fatigue fractured surface of $\mathrm{Fe}-30 \mathrm{Ni}(900)$.

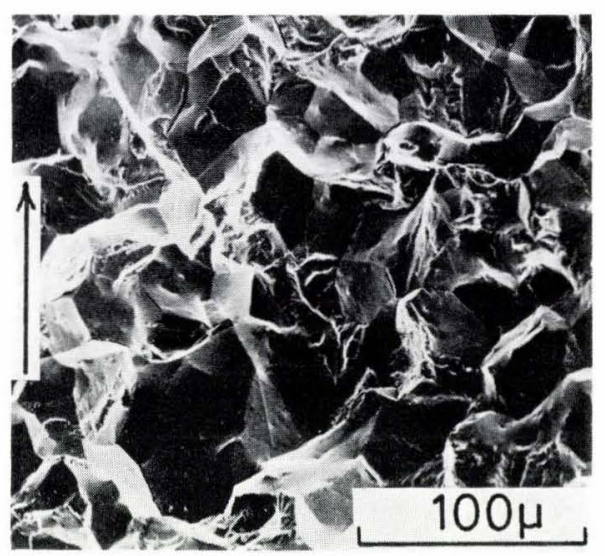

Photo. 6. Fatigue fractured surface of $\mathrm{Fe}-38 \mathrm{Ni}(900): \Delta K=$ $47 \mathrm{~kg} / \mathrm{mm}^{3 / 2}$.

formation only, these plots should produce an approximately straight line. We call this hardening, corresponding to this straight line, HDM (hardening due to martensite formation). The deviation from this line (upward deviation indicates softening and downward deviation hardening) suggests that some factors other than martensite formation also affect the cyclic behavior. But it should be noted that martensite formation also indirectly affects these factors (e.g., the martensite transformation induces stress fields so that it causes softening or hardening).

As shown in this figure, when a stress of $30 \mathrm{~kg} / \mathrm{mm}^{2}$ was applied to $\mathrm{Fe}-30 \mathrm{Ni}$ alloy, it hardened by other factors in addition to HDM in early cycles (for up to 210 cycles), and then softened until $2 \times 10^{3}$ cycles. Further cyclic deformation led to the tendency of only HDM until failure. The behavior at an applied stress of $25 \mathrm{~kg} / \mathrm{mm}^{2}$ was similar to that at $30 \mathrm{~kg} / \mathrm{mm}^{2}$. However, with the decrease of the applied stress the

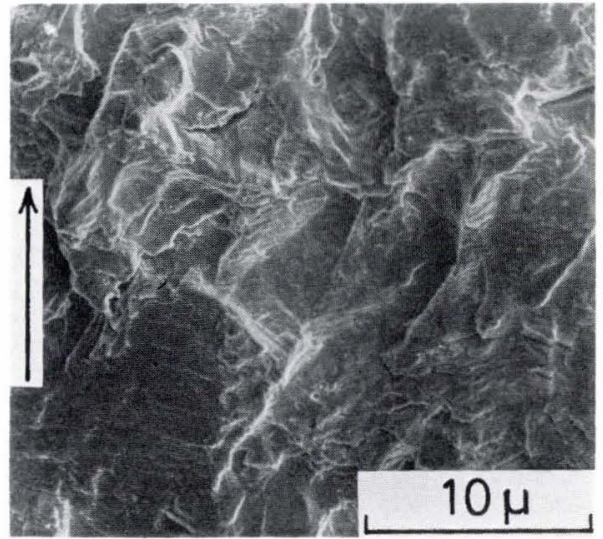

Photo. 7. Fatigue fractured surface of $\mathrm{Fe}-25 \mathrm{Ni}-16 \mathrm{Cr}(950)$ : $\Delta K=47 \mathrm{~kg} / \mathrm{mm}^{3 / 2}$.

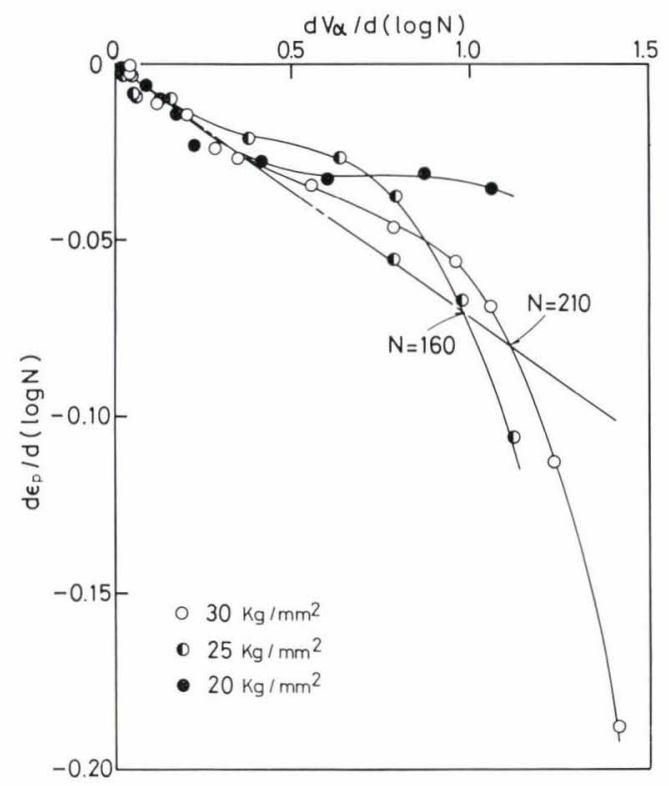

Fig. 10. Relationship between $d V_{\alpha} / d(\log \mathcal{N})$ and $d \varepsilon_{p} /$ $d(\log \mathcal{N}): \mathrm{Fe}-30 \mathrm{Ni}(900)$.

transition in the number of cycles from hardening to softening became shorter and the amount of softening increased. The specimen under an applied stress of $20 \mathrm{~kg} / \mathrm{mm}^{2}$ showed not hardening but softening if HDM were excluded.

The remarkable hardening in early cycles at high stress amplitudes should be interpreted as a work hardening by interaction of dislocations inside or around the induced martensite. Subsequent softening process is attributable to the rearrangement of dislocations, but from this data it is not accurately determined whether it occurred in the austenite phase or in the martensite phase. It was, however, observed by transmission electron microscopy that the dislocation cell structures were produced in austenite phase after cyclic deformation, which might suggest that softening was related to the dislocation rearrangement in austenite phase.

\section{Fatigue Properties of Stable Austenite (Fe-38Ni)}

$\mathrm{Fe}-38 \mathrm{Ni}$ alloy hardens at high stress amplitudes, and the plastic behavior changes from hardening to 
softening with a decrease of applied stress amplitudes. This applied stress dependence of the plastic behavior should be understood by the difference in the introduction and rearrangement of dislocations. Although at high stress amplitudes many dislocations are rapidly introduced in early cycles, they do not rearrange sufficiently in f.c.c. alloys, and the alloys subsequently tend to harden by the interaction of dislocations. meanwhile at low stress amplitudes dislocations introduced are gradually accumulated and rearrange by the coalescence and annihilation of positive and negative dislocations. Subsequently, these alloys soften slightly as in the cases of b.c.c. alloys. ${ }^{13,14)}$

It is noteworthy that such plastic behavior in this alloy is closely analogous to the behavior of $\mathrm{Fe}-30 \mathrm{Ni}$ alloy except HDM. From these results it is considered that at least the softening of $\mathrm{Fe}-30 \mathrm{Ni}$ alloy should also be affected by the dislocation rearrangement in austenite, although it is not clear whether the softening is related to the rearrangement in martensite.

Photograph 1 (c) shows the dislocation structure of $\mathrm{Fe}-38 \mathrm{Ni}$ alloy after fatigued. The cell formation was observed over the specimen, especially near the grain boundaries where stress is concentrated.

\section{Effect of Stacking Fault Energy}

The effects of S.F.E. on the fatigue behavior may be clarified by comparing $\mathrm{Fe}-38 \mathrm{Ni}$ alloy (900) with $\mathrm{Fe}-25 \mathrm{Ni}-16 \mathrm{Cr}$ alloy (950) that have almost the same austenite grain size and the same ultimate tensile strength. The low S.F.E. alloy continued to harden during cyclic deformation and the softening occurred only after the crack initiation (Fig. 7). It seems difficult that the cyclic deformation rearranges the linear dislocations and forms the cell structures in this alloy (Photo. 1 (d)).

As the proof stress of this alloy (950) is $10 \mathrm{~kg} / \mathrm{mm}^{2}$ lower than that of $\mathrm{Fe}-38 \mathrm{Ni}$ alloy (900), a large plastic strain is produced in the former. Therefore, a large strain in early cycles during cyclic deformation is fatal for the low S.F.E. materials.

\section{Initiation of Surface Cracks}

As mentioned above, the initiation sites of fatigue cracks depend upon the applied stress amplitudes in $\mathrm{Fe}-30 \mathrm{Ni}$ alloy, that is, the cracks initiate preferentially in pre- $\gamma$ boundaries at high stress amplitudes and mainly along the interface of austenite/martensite at low stress amplitudes.

This may be explained as follows. The cyclic deformation at high stress amplitudes rapidly produces a large amount of martensite on the surface in the early stage, while the martensite formation is quite small in the subsequent stage when the fatigue cracks are initiated. It is presumable that in this later stage the stress-induced transformation has no relation with the crak initiation which takes place in the pre- $\gamma$ grain boundaries where the martensite lath bundles intersect to generate the stress concentration. On the other hand, at low stress amplitudes both the stress concentration and crack initiation occur at the interface of the austenite phase and the mar- tensite bundles that were produced prior to or subsequent to the early cycling rather than at the pre- $r$ grain boundaries. In this case martensite formation is so moderate that it may strengthen the regions and facilitate the deformation of the surrounding area. As the results, the crack initiation is considerably delayed although the cracks finally initiate in these regions. It is reasonable, therefore, that the fatigue life of this alloy is shorter than that of the stable austenitic alloy of the same strength at high stress amplitudes, whereas it is longer at low stress amplitudes.

In $\mathrm{Fe}-38 \mathrm{Ni}$ alloy or $\mathrm{Fe}-25 \mathrm{Ni}-16 \mathrm{Cr}$ alloy the cracks initiate preferentially at the grain boundaries or twin boundaries at high stress amplitudes, and this may be attributed to the stress concentration at the grain boundaries where the cell structures are well developed (Photo. 1 (c)). On the other hand, the cyclic deformation at low stresses seems to intensify the extrusion-intrusion on the specimen surface and causes cracks to initiate along the slip bands rather than the boundaries.

\section{Fatigue Crack Propagation Properties}

As shown in Fig. 9, fatigue crack propagation property of $\mathrm{Fe}-30 \mathrm{Ni}$ alloy is superior to that of $\mathrm{Fe}-38 \mathrm{Ni}$ alloy at low $\Delta K$ level, but this tendency is reversed at high $\Delta K$ level. This is similar to that of the $\mathrm{S}-\mathrm{N}$ curves (Fig. 2) of both alloys, and suggests that the $\mathrm{S}-\mathrm{N}$ curves of these alloys are affected not only by the crack initiation but also by the propagation (See IV. 4). Fractography (Photo. 5) exhibits that Fe$30 \mathrm{Ni}$ alloy fractures transgranularly at low $\Delta K$, but intergranularly at high $\Delta K$. That is the reason why the crack propagation property of this alloy is poor at higher $\Delta K$ levels. The dependence of fracture morphology on the $\Delta K$ level resembles the applied stress level dependence of the surface crack initiation sites. This is probably related to the rate and period of martensite formation near the crack tips. At low $\Delta K$ the preferred crack paths are along the gradually formed martensite bundles, whereas at high $\Delta K$ levels they are rather along the most stress-concentrated grain boundaries since martensite transformation near the crack tips has been completed.

In $\mathrm{Fe}-38 \mathrm{Ni}$ alloy the intergranular fracture is predominant over the entire $\Delta K$ range, which presumably explains that the crack propagation rate of this alloy is higher than that of $\mathrm{Fe}-30 \mathrm{Ni}$ alloy at low $\Delta K$ level. On the other hand, it is rational that propagation rate of $\mathrm{Fe}-38 \mathrm{Ni}$ alloy is lower than that of $\mathrm{Fe}-30 \mathrm{Ni}$ alloy although the predominant mode of crack growth is intergranular in both alloys, as the latter alloy has already transformed to martensite.

The crack propagation property of $\mathrm{Fe}-25 \mathrm{Ni}-16 \mathrm{Cr}$ alloy is superior to that of other alloys in all the $\Delta K$ range. The fractographic analysis of this alloy in Photo. 7 shows that the cracking occurs in the ductile mode which is characterized by striations and dimples, especially in extremely high $\Delta K$ range.

\section{Conclusions}

An attempt has been made to investigate the fatigue 
behavior of three different austenitic steels. The materials tested are $\mathrm{Fe}-30 \mathrm{Ni}$ alloy as metastable austenite, $\mathrm{Fe}-38 \mathrm{Ni}$ alloy as stable austenite and $\mathrm{Fe}-$ $25 \mathrm{Ni}-16 \mathrm{Cr}$ alloy of low stacking fault energy. The results obtained are as follows.

(1) Comparing the fatigue life of these alloys, it is found that the metastable austenitic alloy is superior to stable alloys at low stress amplitudes, but it is inferior at high stress amplitudes. This tendency seems closely related to the rate and period of martensite formation.

(2) From the relationship between cyclic plastic behavior and martensite transformation in $\mathrm{Fe}-30 \mathrm{Ni}$ alloy, the cyclic plastic behavior except for the hardening due to martensite formation is clarified. This behavior resembles that of $\mathrm{Fe}-38 \mathrm{Ni}$ alloy, that is, at high stress amplitudes hardening is remarkable and at low stress amplitudes softening is predominant.

(3) Fe-25Ni-16Cr alloy of low S.F.E. hardens remarkably during cyclic deformation, especially under high stress amplitudes.

(4) In $\mathrm{Fe}-30 \mathrm{Ni}$ alloy, surface cracks preferentially initiate in pre- $\gamma$ boundaries at high stress amplitudes. At low stress amplitudes, in addition to these sites, they nucleate along the interface of austenite phase and martensite phase. The crack propagation paths also depend on $\Delta K$ level.

(5) The fatigue cracks in $\mathrm{Fe}-38 \mathrm{Ni}$ alloy and $\mathrm{Fe}-$ $25 \mathrm{Ni}-16 \mathrm{Cr}$ alloy are initiated preferentially at austenitic grain boundaries or twin boundaries at high stress amplitudes, whereas mostly along slip bands at low stress amplitudes.

\section{REFERENCES}

1) H. J. French: Trans. ASTM, 21 (1933), 899.
2) P. H. Frith: Iron Steel Inst. Spec. Rep., (1954), No. 50.

3) H. E. Frankel, J. A. Benett and W. A. Pennington: Trans. ASM, 52 (1960), 257.

4) Y. Imai and S. Kumagai: J. Soc. Mat. Sci., Japan, 20 (1971), 1285.

5) Y. Imai and S. Kumagai: J. Soc. Mat. Sci., Japan, 20 (1971), 1292.

6) E. Yajima, T. Miyazaki, T. Sugiyama and H. Terajima: J. Japan Inst. Metals, 36 (1972), 711.

7) B. Prenosil: Tech. Digest, 10 (1968), 222.

8) R. H. Richman and R. W. Landgraph: Met. Trans., 6A (1975), 955.

9) G. R. Chanani, S. D. Antolovich and W. W. Gerberich: Met. Trans., 3A (1972), 2661.

10) G. R. Chanani and S. D. Antolovich: Met. Trans., 5A (1974), 217.

11) A. G. Pineau and R. M. Pelloux: Met. Trans., 5A (1974), 1103.

12) D. Hennessy, G. Steckel and C. Altstetter: Met. Trans., 7A (1976), 415.

13) S. Horibe, R. Sagawa, T. Fujita and T. Araki: Tetsu-toHagané, 64 (1978), 268.

14) S. Horibe, R. Sagawa, T. Fujita and T. Araki: Tetsu-toHagané, 65 (1979), 80.

15) R. L. Miller: Trans. ASM, 57 (1964), 892.

16) D. Bhandarker, V. F. Zackay and E. R. Parker: Met. Trans., 3 (1972), 2619.

17) J. F. Breedis and W. D. Robertson: Acta Met., 10 (1962), 1077.

18) J. F. Breedis and W. D. Robertson: Acta Met., 11 (1963), 547.

19) R. P. Carreker and W. R. Hibbard: Acta Met., 1 (1953), 654.

20) G. W. Geil and N. L. Carwile: NBS Circular 520, Mechanical Properties of Metals at Low Temperatures, (1952), 67.

21) B. Gross and J. E. Srawley: NASA Technical Note, No. D-2603, NASA, (1965), Jan. 